\title{
Static and dynamic behavior of concrete slabs reinforced with chemically reactive enamel-coated steel bars and fibers”
}

\author{
Dong-ming YAN ${ }^{1}$, Shi-kun CHEN $^{1}$, Gen-da CHEN $^{\dagger \ddagger 1,2}$, Jason BAIRD ${ }^{2}$ \\ $\left({ }^{1}\right.$ School of Civil and Architectural Engineering, Zhejiang University, Hangzhou 310058, China) \\ ( ${ }^{2}$ Department of Civil, Architectural, and Environmental Engineering, Missouri University of Science and Technology, \\ Rolla, MO 65409-0330, USA) \\ †E-mail: gdchen@zju.edu.cn
}

Received Nov. 4, 2015; Revision accepted Feb. 26, 2016; Crosschecked Apr. 7, 2016

\begin{abstract}
In this study, the effect of steel fibers coated with chemically reactive enamel (CRE) on the system response of concrete structures with reinforcing bars has been investigated for the first time. In particular, the ultimate strength, ductility, and failure mechanism of 24 reinforced concrete slabs were experimentally characterized under static and blast loads. CRE coating applied on steel bars reduced the crater area of slabs under blast loads by up to $20 \%$; it slightly increased the strength of slabs and significantly reduced the strength degradation of slabs when increasingly deflected under static loads, making the slabs more ductile. CRE coating applied on steel fibers increased the strength of slabs by up to $16 \%$ under static loads. The influence of CRE coating applied on both steel fibers and bars may be taken into account by introducing a coating factor in the range of $0.57<\beta<1.0$ in the American Concrete Institute (ACI) development length equation.
\end{abstract}

Key words: Chemically reactive enamel (CRE) coating, Blast load, Fracture pattern, Steel fibers http://dx.doi.org/10.1631/jzus.A1500301

CLC number: TH161.12

\section{Introduction}

The corrosion of steel bars in reinforced concrete (RC) structures has been a main concern in civil engineering for many decades. Today, the longlasting concern becomes ever more serious as more civil infrastructure has been built in modern society. For example, the deterioration of steel bars caused by corrosion accounts for over $60 \%$ of annual expenditures by state and federal transportation agencies on bridge maintenance, repair or replacement in the USA. Therefore, numerous attempts have been made

\footnotetext{
Corresponding author

* Project supported by the National Natural Science Foundation of China (Nos. 51379186 and 51522905), the Zhejiang Provincial Natural Science Foundation of China (No. LR15E090001), and the Leonard Wood Institute under Award (No. LWI61009), USA

(D) ORCID: Dong-ming YAN, http://orcid.org/0000-0003-2522-3342; Gen-da CHEN, http://orcid.org/0000-0002-0658-4356

(C) Zhejiang University and Springer-Verlag Berlin Heidelberg 2016
}

to prevent/delay the corrosion of embedded steel with protective coating while improving the bonding of coated steel bar in concrete as evidenced from the following summary review.

\subsection{Corrosion-resistant coatings of steel bar}

In recent years, quite a few methods have been developed to tackle the corrosion problem of steel bar, such as corrosion inhibitor, catholic protection, and protective coating. Among them, corrosion-resistant coating has been regarded as one of the direct, efficient, and cost-effective ways to prevent or delay the corrosion process of rebar in concrete structures. Since the 1990s, various coatings have been developed and applied to steel bar as a physical barrier to chloride or carbon invasion. They can be categorized into organic (e.g., fusion-bonded epoxy), metallic (e.g., zinc and copper), and inorganic (e.g., phosphate and enamel) coatings. Epoxy coating has been widely used in civil engineering due to its cost effectiveness 
and, when intact, its ability to keep chloride or carbon out of the surface of steel bar (Brown and Weyers, 2003). When damaged during construction, however, epoxy coating could accelerate the corrosion process of steel bar since moisture can be trapped between the coating and steel bar (Sagues, 1994; Zhao et al., 2007). Zinc coating can delay steel bar from corrosion (Dong et al., 2012) but is usually more expensive than epoxy coating. Recently, chemically reactive enamel (CRE) coatings have been shown to significantly improve the corrosion resistance of steel bar (Tang et al., 2012a; 2012b; 2013). Due to their high corrosion resistance and low cost, they are promising for extensive applications in civil infrastructure particularly when built in corrosive environment.

\subsection{Effect of corrosion-resistant coatings on the mechanical properties of steel bar}

Various coatings are mainly introduced for corrosion protection. However, their effect on the mechanical properties of steel bar may impact the defection and integrity of RC structures and thus must be investigated as well. In general, metallic coatings do not change the bond strength of steel bar in concrete. For example, Kayali and Yeomans (2000) concluded that the galvanized steel had negligible effect on the steel-concrete behavior. The adhesion between the zinc coating and its surrounding concrete paste is weak due to the formation of a weak interfacial transition zone in the paste. Organic coatings are deemed to weaken the steel-concrete bond in RC structures. The interfacial transition zone between epoxy coating and its surrounding concrete is even weaker than the use of zinc coating. Therefore, the development length of epoxy-coated rebar is significantly increased as prescribed in ACI (2014) and AASHTO (2015). The shortest length to ensure that the yield strength of a steel bar can be developed is referred to as "development length" in concrete structures (MacGregor, 1997). To effectively transfer stress from a steel reinforcing bar to its surrounding concrete, it is necessary to provide an additional length of the bar over which the stress can be linearly reduced to zero through the accumulation of weak chemical bonds on the steel-concrete interface. Inorganic coatings, such as phosphate and CRE coatings, can significantly improve the adhesion and friction between steel bar and concrete. Jalili et al. (2009) indicated that the bond strength between the $\mathrm{Zn}-\mathrm{Ca}$ phosphate-coated rebar and concrete is $74 \%$ greater than that between uncoated rebar and concrete. CRE coating can also significantly increase the bond strength of rebar in concrete matrix (Day et al., 2006; Wu et al., 2012; Yan et al., 2012). For example, Yan et al. (2012) observed an increase of 6 times in bond strength by the CRE coating. The CRE coating, particularly when mixed with calcium silicate, provided an excellent transition medium between the steel and concrete and minimized the so-called interfacial transition zone in RC structures through chemical reactions with both steel and concrete.

Due to its increased bond strength between rebar and surrounding concrete (Yan et al., 2012), CRE coating can influence the deflection and failure mode of RC structures under static loads. Wu et al. (2013) concluded that the CRE coating can change the structural behavior of RC beams from a brittle concrete splitting failure to a nearly ductile steel yielding failure. However, the effect of CRE coating on the mechanical behavior or failure model of RC slabs under dynamic loading is yet to understand, particularly when CRE-coated steel fibers are added to the slabs. It is of great significance to obtain a full view of the effect that CRE coating has on the mechanical behavior and failure mode of slabs before enamel coating is introduced to the practical design of concrete structures for various performance objectives, such as blast load resistance (Dusenberry, 2010), punching failure prevention under point loads, and bending failure prevention under line loads (ACI, 2014).

This paper aims to investigate the effect of CRE coating on the overall behavior of concrete slabs reinforced with steel bars and fibers under static and dynamic loading. In particular, the ultimate load, maximum deflection, and failure mode of slabs with uncoated and CRE-coated reinforcement are compared. The test data are unique and enable the validation of computational models in future development.

\section{Experimental}

\subsection{Materials and mechanical properties}

The CRE coating used in this study consisted of $50 \%$ (in weight) commercial enamel and 50\% reactive calcium silicate that was taken from Type I 
Portland cement (Tang et al., 2012a; 2012b; 2013). It was introduced to increase the bond strength between steel bar and concrete by increasing the surface roughness of coated steel bar for frictional effect or mechanical bonding and by promoting the chemical reaction of enamel with concrete for adhesive effect or chemical bonding (Wu et al., 2012; Yan et al., 2012).

Enamel is typically silicate-based oxides that are deposited from slurries and fused at high temperature. The mixed enamel slurry was made by first mixing $227 \mathrm{~kg}$ alkali borosilicate glass frits and $227 \mathrm{~kg}$ calcium silicate in Portland cement with $189.3 \mathrm{~kg}$ water for $20 \mathrm{~min}$, then adding $31.8 \mathrm{~kg}$ clay and $2.27 \mathrm{~kg}$ borax as suspension agents, and finally mixing them again for $3.5 \mathrm{~h}$. The alkali borosilicate glass frit was selected because it contained $\mathrm{ZrO}_{2}$ for enamel resistance in alkaline environments, and $\mathrm{NiO}$ and $\mathrm{CoO}$ for enamel adherence on steel bar (NRC, 1927).

Prior to coating, all steel bars were sand-blasted and cleansed with a commercially available cleansing solvent. The clean steel bar was dipped into the mixed enamel slurry, heated for $2 \mathrm{~min}$ at $150{ }^{\circ} \mathrm{C}$ to drive off moisture, fired at $810{ }^{\circ} \mathrm{C}$ for $10 \mathrm{~min}$, and finally cooled to room temperature. The firing treatment at high temperature was used to melt the glass frit and chemically bond the enamel to the steel bar. Typical CRE coating is shown in Fig. 1.

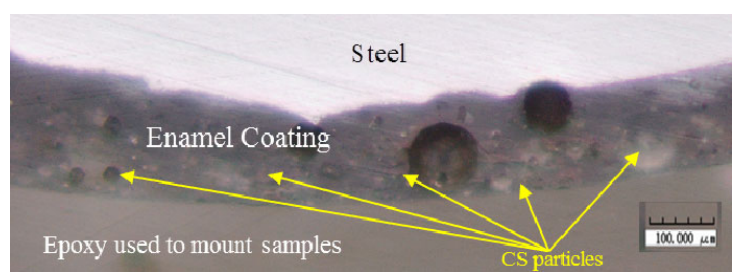

Fig. 1 Typical CRE coating $\mathrm{CS}$ is calcium silicate

Type I Portland cement and Grade \#410 steel bar with nominal yield strength of $490 \mathrm{MPa}$ were used to fabricate all slab specimens. At the time of concrete casting, three concrete cylinders were cast and used to determine the compressive strength of concrete. After $28 \mathrm{~d}$ of curing, the average compressive strength of concrete is $44.0 \mathrm{MPa}$ with a standard deviation of $1.38 \mathrm{MPa}$; the average modulus of elasticity is $31.5 \mathrm{GPa}$ with a standard deviation of $0.827 \mathrm{GPa}$.

\subsection{Specimen fabrication}

Each slab specimen was $1200 \mathrm{~mm} \times 1200 \mathrm{~mm}$ $\times 90 \mathrm{~mm}$ with reinforcement details as illustrated in Fig. 2. The size of the slab was chosen with the intent of comparing the effect of CRE coating with other technologies used to improve the blast hardening of RC structures (Silva and Lu, 2007). The slab was reinforced with \#10 steel bars $(9.525 \mathrm{~mm}$ in diameter) with a main reinforcement ratio of $0.5 \%$ and additional steel fibers $(0.737 \mathrm{~mm}$ in diameter $)$ as needed. The steel bars were cut into the required length before they were coated. The steel fibers were coated before the CRE-coated steel wires were cut into pieces as required. Glass fibers were also prepared and used for comparison.

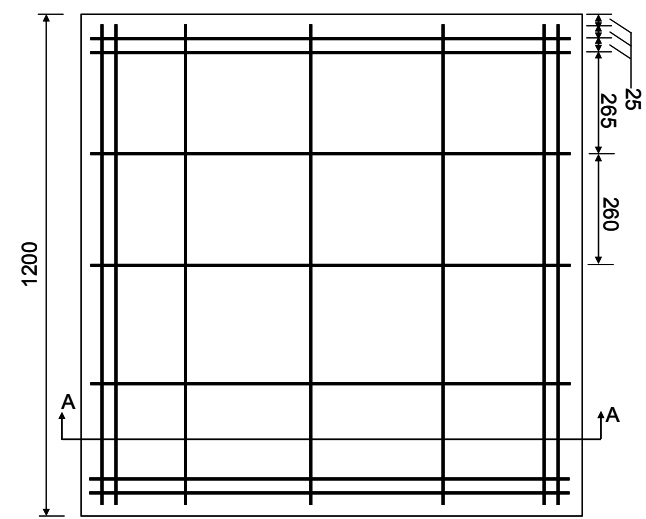

(a)

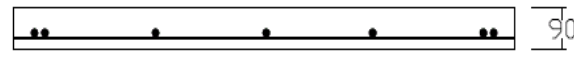

(b)

Fig. 2 Reinforcement details of slab (unit: $\mathbf{m m}$ ) (a) Plane view; (b) Cross section view (A-A)

A total of 24 slabs (8 groups designated as $\mathrm{A}-\mathrm{H}$, and 3 slabs in each group) were prepared as shown in Table 1. Slabs in Groups A and B were reinforced with uncoated steel bars and the remaining slabs with CRE-coated steel bars. In addition to steel bars, steel fibers with different lengths were mixed into concrete slabs in Groups E, F, and G, and glass fibers were mixed into concrete in Group $\mathrm{H}$. The slabs in Groups $\mathrm{A}$ and $\mathrm{C}$ were tested under blast loads and the remaining slabs were tested under static loads. Each slab is designated by a group letter in Table 1, followed by a number $(1,2$, or 3$)$ in that group. For 
Table 1 Test metrics of all RC slabs

\begin{tabular}{|c|c|c|c|c|c|c|}
\hline \multirow{2}{*}{ Group } & \multirow{2}{*}{ Steel bar coating } & \multicolumn{4}{|c|}{ Fibers } & \multirow{2}{*}{ Load type } \\
\hline & & Type & Fiber coating & Length (mm) & Dosage (\%) & \\
\hline A & No & - & - & - & - & Blast load \\
\hline $\mathrm{C}$ & Yes & - & - & - & - & Blast load \\
\hline $\mathrm{D}$ & Yes & - & - & - & - & Static point load \\
\hline $\mathrm{F}$ & Yes & Steel & Yes & 29.5 & 1.0 & Static line load \\
\hline G & Yes & Steel & Yes & 59.0 & 1.0 & Static line load \\
\hline $\mathrm{H}$ & Yes & Glass & - & 29.5 & 1.0 & Static line load \\
\hline
\end{tabular}

example, Slab A1 means the first slab in Group A, which is reinforced with uncoated bars only (no fibers) subjected to blast loading.

\subsection{Blast test procedure}

Blast tests were conducted at the Missouri S\&T Experimental Mine, USA. Two slabs were tested in three steps and four slabs in one step as summarized in Table 2. Each slab was placed on top of two steel I-beams with $127 \mathrm{~mm}$ bearing length at each end. A charge, which was a pack of 8-32 detonators of $12 \mathrm{~cm}$ in length and $2.5 \mathrm{~cm}$ in diameter each, was hung above the center point of the slab at a specified standoff distance measured from the center of explosive to the top face of the test slab as shown in Fig. 3. Various combinations of charge weights and standoff distances used in the blast tests are also listed in Table 2. No instrumentation was deployed on the slab due to its destructive working environment. After each test, the permanent deflection at mid-span was measured with a measurement tape and the width of cracks was measured using a crack microscope.

\subsection{Static test procedure}

For static tests, two load protocols were adopted to study the failure modes of slabs: point load and line load. The point load was used to characterize the resistance of slabs to punching failure, and the line load was to simulate the flexural behavior of one-way slabs.

The test setups under a point load and a line load are illustrated in Figs. 4a and 4b. All slabs were simply supported on two I-beams, similar to the blast tests. The static tests were performed in displacement control to ensure that a complete load-deformation curve can be obtained for each slab. The point load
Table 2 Blast test plan

\begin{tabular}{cccc}
\hline Slab & Step & $\begin{array}{c}\text { Charge } \\
\text { weight }(\mathrm{kg})\end{array}$ & $\begin{array}{c}\text { Standoff } \\
\text { distance }(\mathrm{cm})\end{array}$ \\
\hline \multirow{2}{*}{$\mathrm{A} 1, \mathrm{C} 1$} & 1 & 0.45 & 91.4 \\
& 2 & 1.14 & 30.5 \\
\hline $\mathrm{A} 2, \mathrm{C} 2$ & 1 & 1.73 & 20.3 \\
\hline $\mathrm{A} 3, \mathrm{C} 3$ & 1 & 1.14 & 30.5 \\
\hline
\end{tabular}

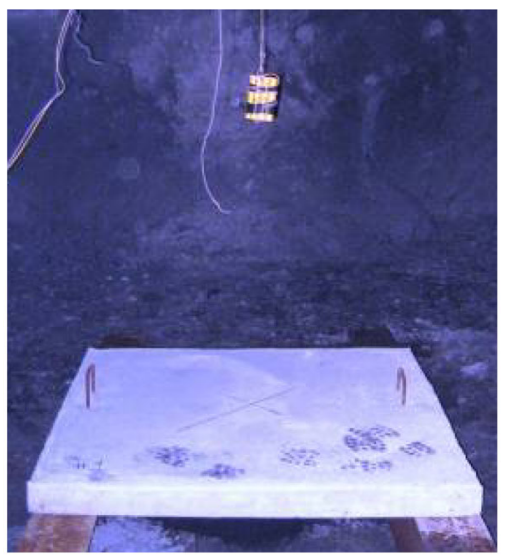

Fig. 3 Blast test setup

was applied at the center of each slab; the line load was applied along the mid-span of each slab between two support beams. The loading mechanism for the line load consists of a load beam, two rollers, a load distribution beam, and a plywood sheet. The load generated by a hydraulic actuator was first applied to the load beam, and then transferred to the distributed beam through the two rollers between the two beams. Finally, the applied load was distributed to the slab with the distribution beam. Plywood sheet was used to ensure that the distribution beam is in close contact with the slab to minimize the influence of any uneven 
slab surface. Each slab was instrumented with eight linear variable differential transformers (LVDTs) to measure the displacement of the slab during testing. The respective LVDT locations are also illustrated in Fig. 4.

\section{Test results and analysis}

\subsection{CRE coating effect on the resistance of slabs under blast loading}

Since they were not tied to supports during blast tests, slabs sometimes experienced significant movement at the supports. The residual vertical
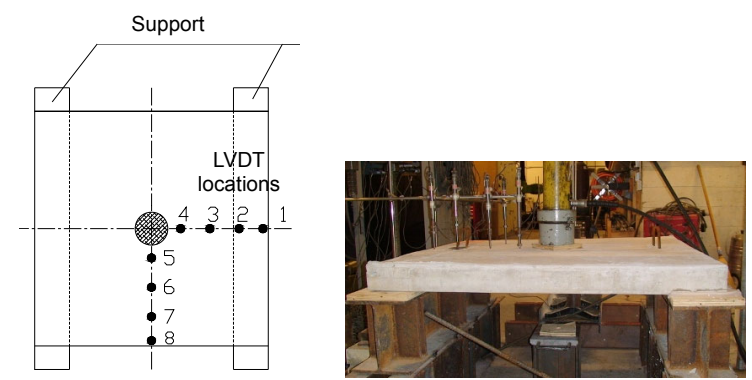

(a)
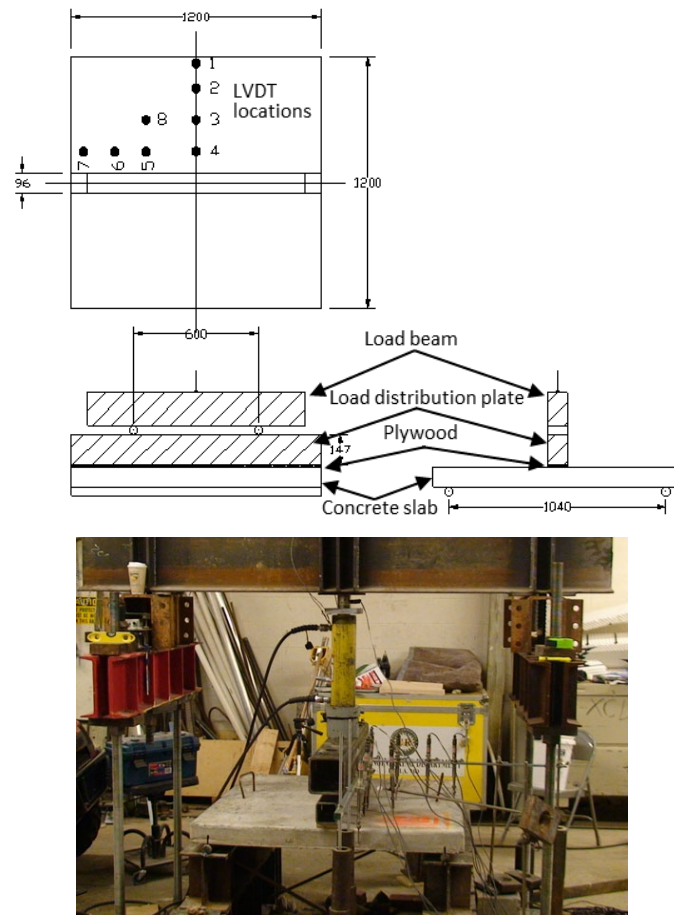

(b)

Fig. 4 Static test setup and instrumentation (unit: $\mathbf{m m}$ ) (a) Point load tests; (b) Line load tests deflections of the slabs may not represent their actual deflection that could occur if they had been restrained from lateral movement. For this reason, residual deflections were not analyzed in this paper.

Slabs $\mathrm{A} 1$ and $\mathrm{C} 1$ were both tested in three steps as detailed in Table 2. In Step 1, no visible damage was detected except for a few small dents or chips, as shown in Fig. 5a. In Step 2, a number of cracks were observed on both slabs with insignificant differences in the relative damage patterns, as shown in Fig. 5b. In Step 3, a large hole was punched through each slab, as shown in Fig. $5 \mathrm{c}$.

To quantify the effect of rebar coating on the behavior of RC slabs subjected to blast loading, the area of a crater or hole punched through each slab by explosives was measured and normalized by the total area of the respective slab in virgin state. For example, the crater areas on Slabs A1 (with uncoated reinforcement) and $\mathrm{C} 1$ (with coated reinforcement) were found to be $37.3 \%$ and $31.4 \%$, respectively. These results indicate that CRE coating can reduce the crater area of RC slabs by approximately $16 \%$.

To avoid the effect of accumulative damage from small charges on the formation of craters, the remaining slabs were tested using a single charge as shown in Table 2. Fig. 6a compares the damage patterns on Slabs A2 and C2 after the explosive tests with a $1.14 \mathrm{~kg}$ charge weight at a standoff distance of $30.5 \mathrm{~cm}$. The crater created on Slab A2 is deeper than the corresponding crater on Slab C2. Similarly, Fig. $6 \mathrm{~b}$ compares the damage patterns on Slabs A3 and $\mathrm{C} 3$ due to the blast loads with a charge weight of $1.73 \mathrm{~kg}$ at a standoff distance of $20.3 \mathrm{~cm}$. The crater area on the bottom face of Slab A3 (53.3\%) is significantly larger than that of Slab C3 (42.6\%), a 20\% reduction due to $\mathrm{CRE}$ coating. Both comparisons confirm the increase in blast resistance of the concrete slabs reinforced with CRE-coated bars. The effect of CRE coating can further be verified through a forensic investigation on the tested slabs. After the blast tests with $1.14 \mathrm{~kg}$ equivalent TNT, concrete debris was completely stripped off the uncoated bars as shown in Fig. 7a, but remained on the CRE-coated bars as shown in Fig. 7b. This comparison suggested that a stronger bond between the CRE-coated bars and concrete has been achieved, contributing to the formation of a smaller crater on the tested slabs as discussed in Fig. 6. 

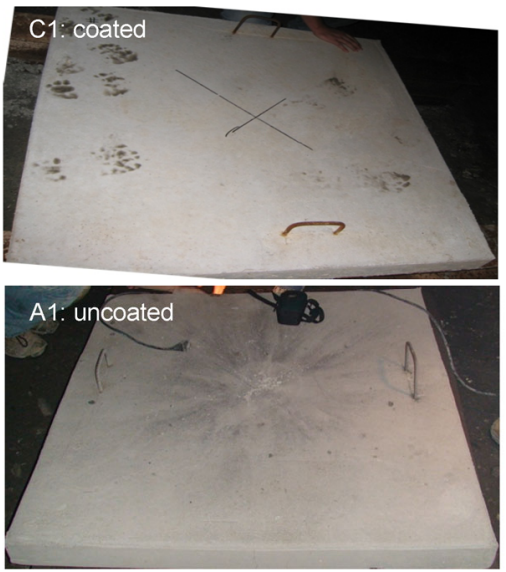

(a)
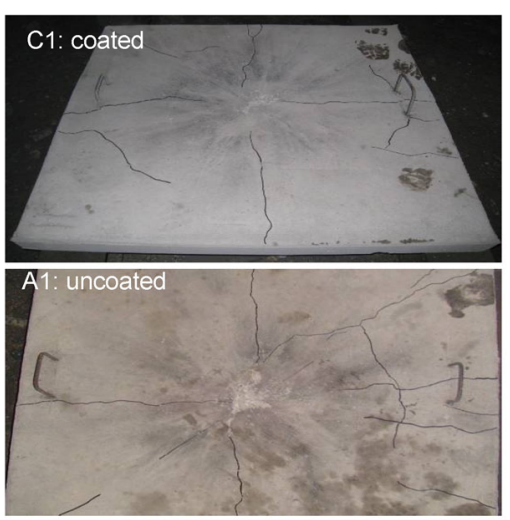

(b)
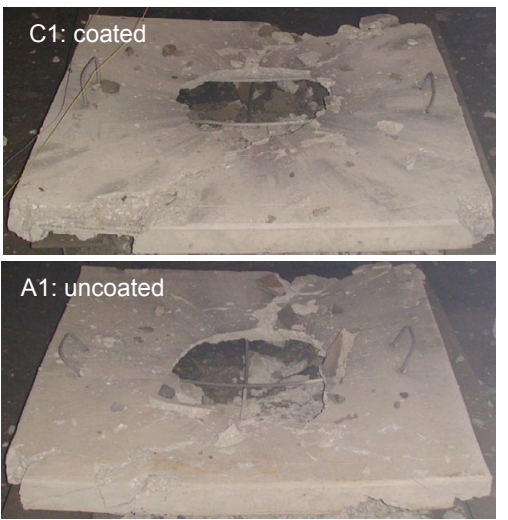

(c)

Fig. 5 Slab damage patterns after blast tests (top side) (a) Step 1; (b) Step 2; (c) Step 3

By comparing Fig. 6 with Fig. 5, it can be clearly observed that the crater area due to a single charge is over $20 \%$ larger than that due to three charges. The significant effect of accumulative damage is attributed to the fact that, once a crater is formed due to a small charge, the air pressure induced by the

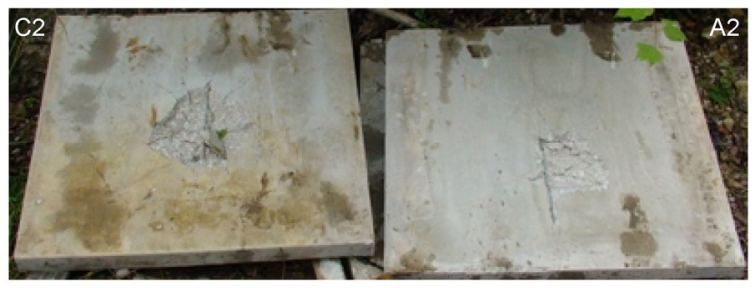

(a)

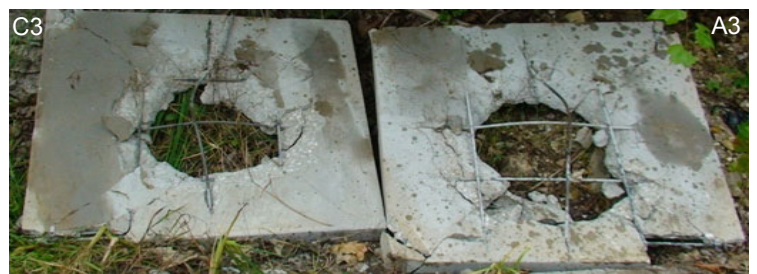

(b)

Fig. 6 Slab damage patterns after blast tests (back side) (a) $1.14 \mathrm{~kg}$ charge weight and $30.5 \mathrm{~cm}$ standoff distance; (b) $1.73 \mathrm{~kg}$ charge weight and $20.3 \mathrm{~cm}$ standoff distance
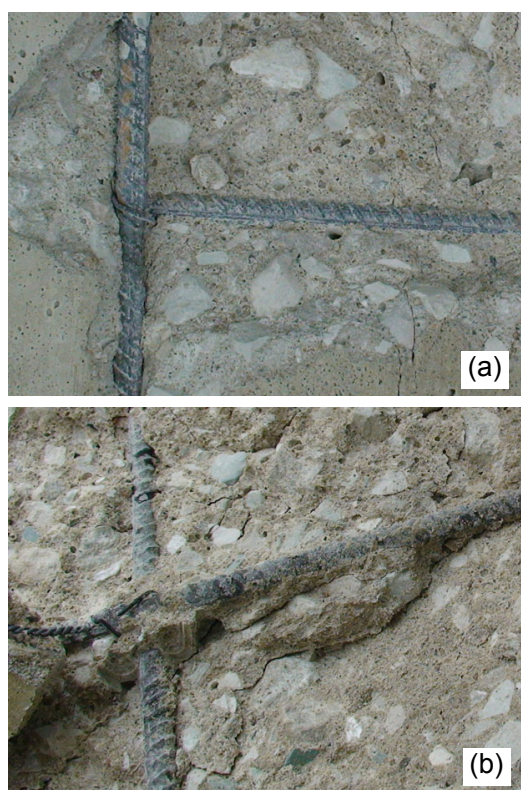

Fig. 7 Steel bars after blast tests (back side) (a) Uncoated bars in Slab A2; (b) Coated steel bars in Slab C2

following large charge can escape from the crater and cause little or no additional damage.

\subsection{CRE coating effect on the role of steel bars in static behavior of RC slabs}

Three slabs in Group B with uncoated reinforcing bars and three slabs in Group D with CRE-coated reinforcing bars, as described in Table 1, were tested under point loading. The failure modes of one 
representative Slab B3 with uncoated bars and one representative Slab D1 with coated bars are presented in Fig. 8. By comparing the number of cracks on the top and bottom faces of the two slabs, it can be seen that a larger number of minor cracks were observed on the slab reinforced with CRE-coated bars. Figs. 9a and $9 \mathrm{~b}$ show the applied load as a function of the measured deflections at various locations for the two representative slabs. Overall, the measured deflections are very consistent since, the closer to the point load the sensors, the larger the measured deflections. Note that Sensor 1 reported the positive deflections since the top of the slab support was displaced upward as the slab was pushed downward. For direct comparison, the load-deflection curves of the two slabs corresponding to the Sensor 4 measurements are presented in Fig. 9c. The curve of the slab reinforced with CRE-coated bars generally has broader plateaus and less degradation in ultimate strength, indicating a relatively ductile behavior. Note that the loaddeflection curves at the locations of Sensors 2 and 8 in

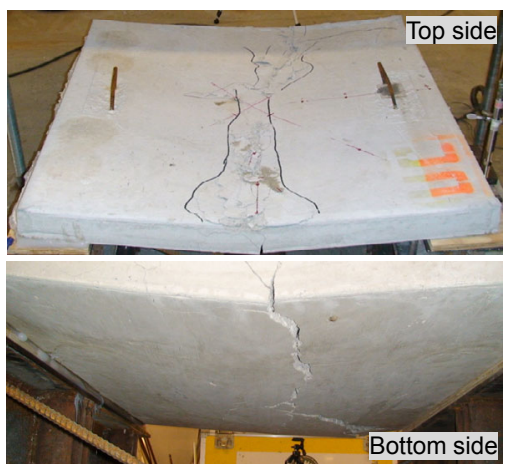

(a)

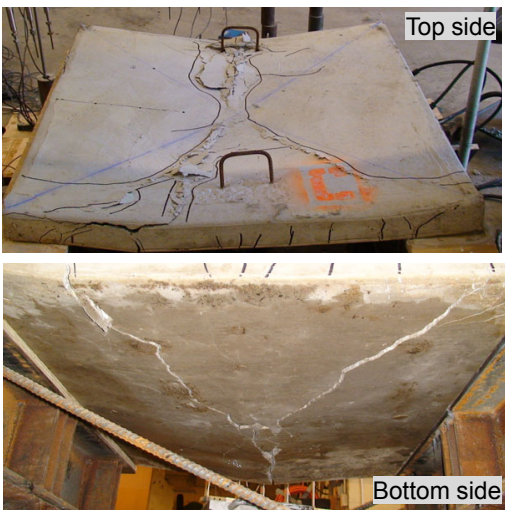

(b)

Fig. 8 Typical failure modes of slabs under a point load (a) Slab B3 with uncoated reinforcing bars; (b) Slab D1 with CRE-coated reinforcing bars
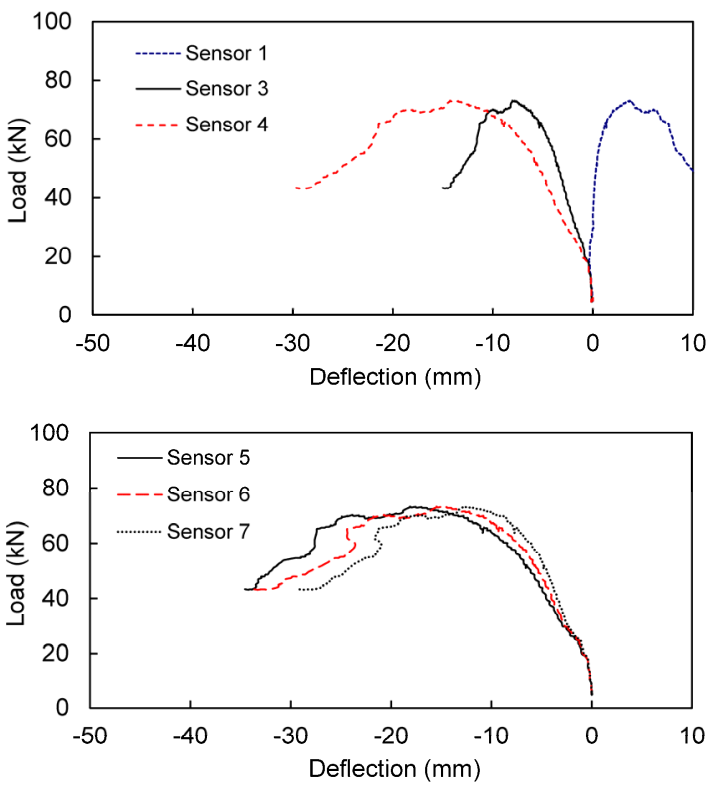

(a)
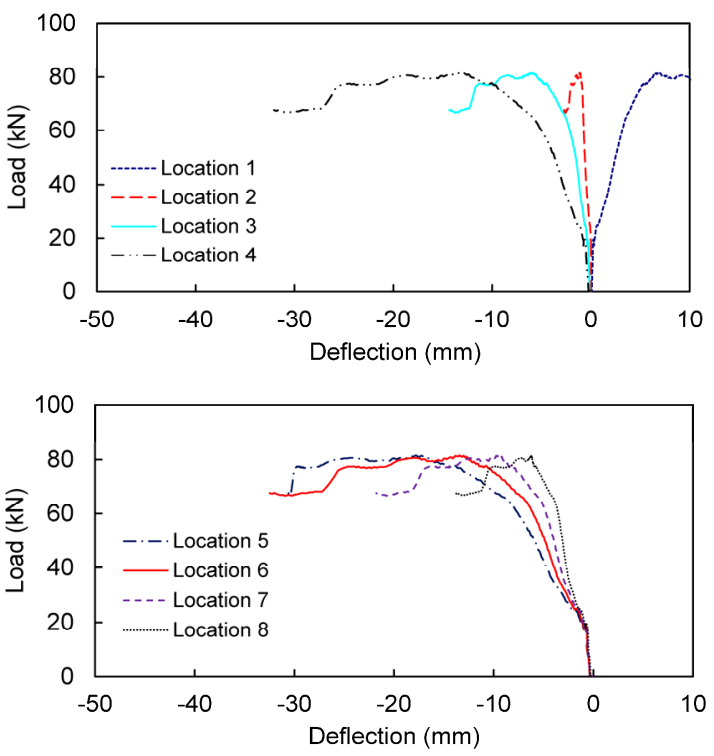

(b)

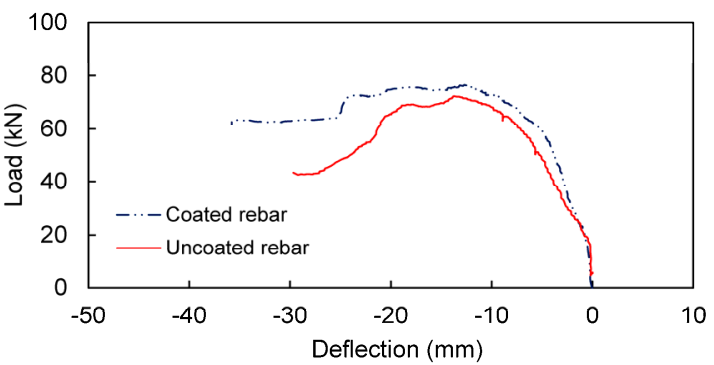

(c)

Fig. 9 Load-deflection curves of two slabs under a point load

(a) Slab B3 with uncoated reinforcing bars; (b) Slab D1 with CRE-coated reinforcing bars; (c) A comparison at the location of Sensor 4 
Slab B3 were unavailable due to their malfunction during tests.

The average and coefficient of variation (COV) of the ultimate strengths from three specimens are summarized in Table 3 for slabs in various groups. The strength difference between Group B and Group $\mathrm{D}$ is negligible. The strength variation of the slabs reinforced with CRE-coated bars is larger than that of the slabs with uncoated bars. This is likely attributed to the inconsistency of CRE coating on the surface of deformed bars as a result of gravity effect during enameling (Tang et al., 2012a).

\subsection{CRE coating effect on the role of steel fibers in static behavior of RC slabs}

Three slabs in each of Groups E-H as shown in Table 1 were tested under line loading. For each group, the test results and behavior of one representative slab are discussed in details. Figs. 10a-10d show the load-deflection curves of four slabs (E2, F3, G2, and H3), respectively, and Fig. 10e compares the load-deflection curves of the four slabs corresponding to the deflection measurements at Sensor 4. Like the test data and results under point loads, the shapes of various load-deflection curves and the measured deflections from various sensors as shown in Figs. 10a-10d are generally consistent under line loads. By comparing the four curves in Fig. 10e, it can be found that the ultimate strength and ductility of Slab F3 with $1 \%$ short CRE-coated fibers are higher than those of Slab E2 with $1 \%$ uncoated fibers. At $1 \%$ dosage, long steel fibers in Slab G2 give a significantly higher strength and ductility than short steel fibers in Slab F3. The Slab H3 with $1 \%$ glass fibers has slightly lower ductility than the Slab F3 with 1\% short CRE-coated steel fibers while their ultimate strengths are comparable. This is because both fibers are too short to have their full strength developed. The strength and ductility of the Slab $\mathrm{H} 3$ are higher than those of the Slab E2 with 1\% uncoated steel fibers.

Table 3 shows that although their variation is relatively high, the ultimate strengths of the three slabs reinforced with $1 \%$ short CRE-coated steel fibers have a higher average value than that of the slabs with $1 \%$ uncoated steel fibers. The use of long fibers within a practical limit increases the ultimate strengths of slabs with less variation. At a given volume, glass fibers can increase the ultimate strength as effectively as but more consistently than steel fibers that were coated with CRE.

It can also be observed from Table 3 that, in comparison with point loads (slabs in Groups B and D), line loads (slabs in Groups E and F) induce smaller ultimate strengths even though the slabs in Groups $\mathrm{E}$ and $\mathrm{F}$ are reinforced with additional short fibers. This is because the failure mechanisms under the two loads are quite different. Under a line load, each slab is forced to form one yield line along the mid-span of the slab as shown in Fig. 11 (p.375). Under a point load, one or more of approximately $45^{\circ}$ yield lines were developed as illustrated in Fig. 8. The increase in the length of all yield lines results in a greater plastic moment and load capacity.

\subsection{Fracture mechanism of slabs reinforced with CRE-coated steel bars and fibers}

The failure modes of the four slabs (E2, F3, G2, and H3) under line loads are illustrated in Fig. 11. Most of these failure modes are associated with a major crack on the bottom face of slabs along the line load and a few minor cracks towards the edges of the slabs.

As observed in Fig. 12 (p.375), a thin layer of mill scale is weakly formed on the surface of a steel bar and the interfacial transition zone of concrete adjacent to the mill scale is porous and weak due to

Table 3 Ultimate strengths of various slabs under static loads

\begin{tabular}{|c|c|c|c|c|c|c|}
\hline \multirow[b]{2}{*}{ Slab } & \multicolumn{2}{|c|}{ Ultimate strength (point load) $(\mathrm{kN})$} & \multicolumn{4}{|c|}{ Ultimate strength (line load) (kN) } \\
\hline & $\begin{array}{c}\text { Uncoated steel } \\
\text { bars (B) }\end{array}$ & $\begin{array}{l}\text { Coated steel } \\
\text { bars (D) }\end{array}$ & $\begin{array}{l}1 \% \text { short uncoated } \\
\text { fibers }(\mathrm{E})\end{array}$ & $\begin{array}{l}1 \% \text { short coated } \\
\text { fibers }(F)\end{array}$ & $\begin{array}{l}1 \% \text { long coated } \\
\text { fibers }(\mathrm{G})\end{array}$ & $\begin{array}{l}1 \% \text { short glass } \\
\text { fibers }(\mathrm{H})\end{array}$ \\
\hline 1 & 79.0 & 84.4 & 70.4 & 54.9 & 76.3 & 76.3 \\
\hline 2 & 79.0 & 74.0 & 54.0 & 69.5 & 83.1 & 74.9 \\
\hline 3 & 77.6 & 74.0 & 59.5 & 89.9 & 79.9 & 71.7 \\
\hline Average & 78.5 & 77.5 & 61.3 & 71.4 & 79.8 & 74.3 \\
\hline $\mathrm{COV}$ & 0.1 & 0.4 & 0.6 & 1.1 & 0.2 & 0.1 \\
\hline
\end{tabular}



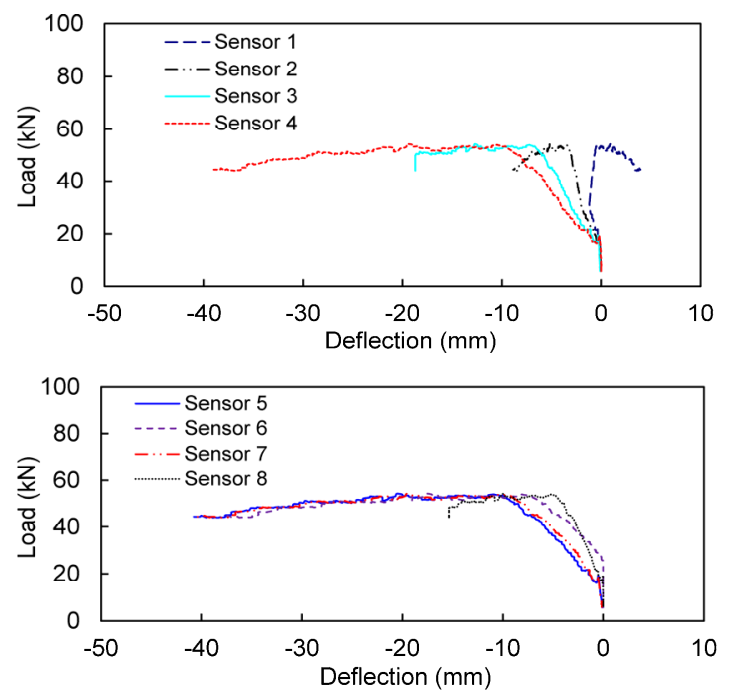

(a)
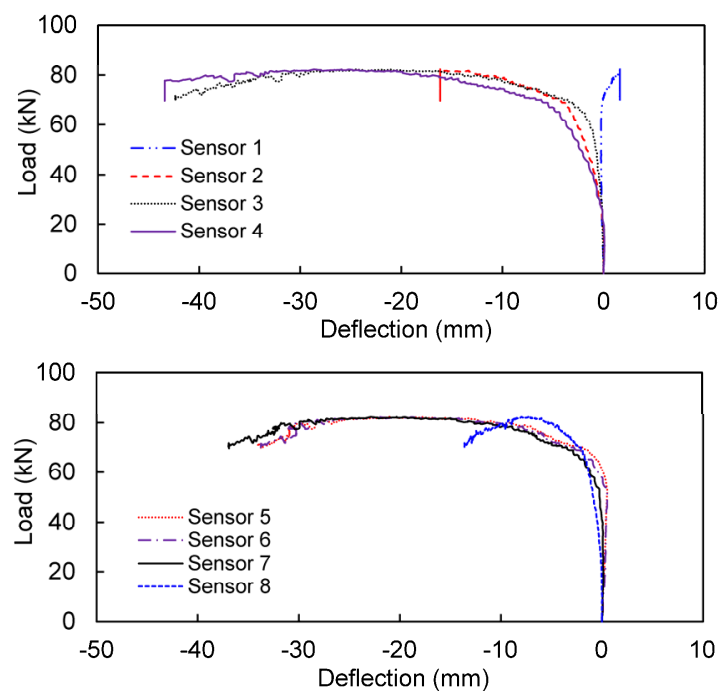

(c)

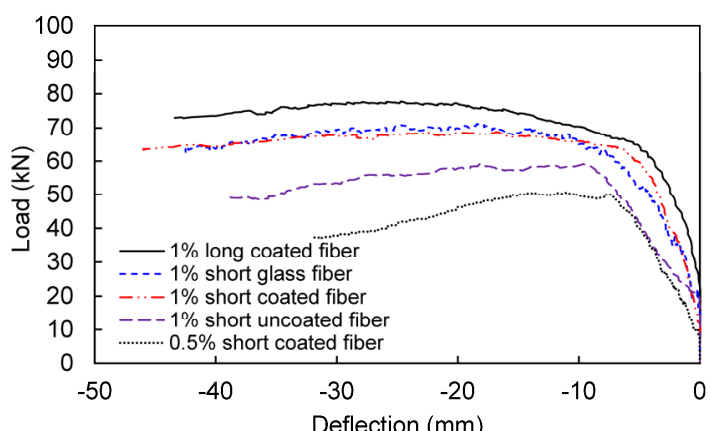

(e)

the concentration of free water (Mindess et al., 2003; Allison et al., 2012). The bond strength between the uncoated bar and concrete is thus low. With CRE coating applied on a steel bar, the microstructure of the transition zone of concrete is less porous and the interfacial strength is greatly improved because of their
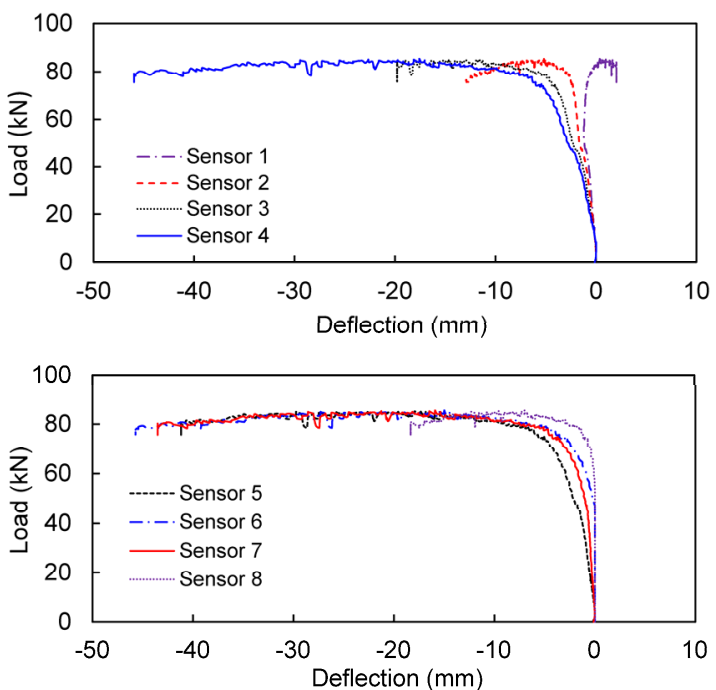

(b)
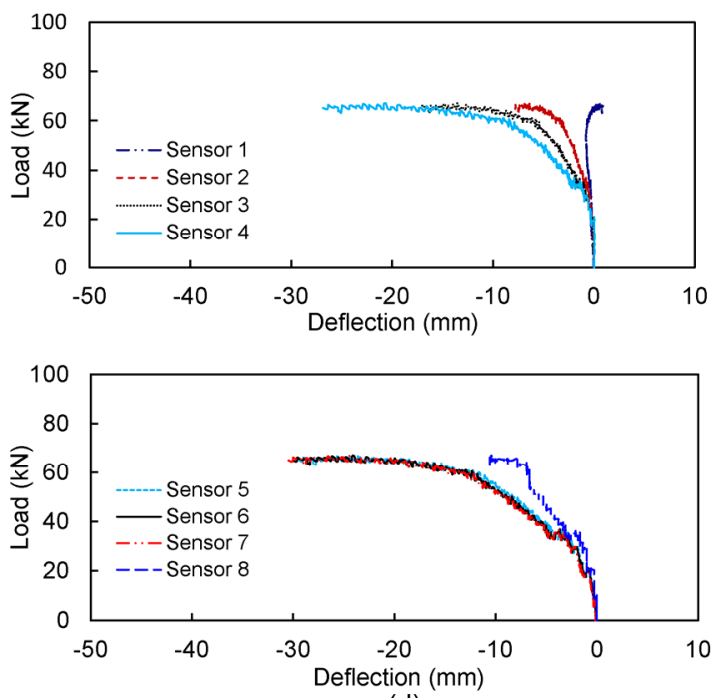

(d)

Fig. 10 Load-deflection curves of slabs with coated steel bars

(a) Slab E2 with 1\% short uncoated fibers; (b) Slab F3 with $1 \%$ short CRE-coated fibers; (c) Slab G2 with $1 \%$ long CRE-coated fibers; (d) Slab H3 with 1\% short uncoated glass fibers; (e) A comparison at the location of Sensor 4

chemical reaction (Wu et al., 2012; Tang et al., 2016). Therefore, the CRE-coated bar is strongly adhered to its surrounding concrete as demonstrated in Fig. 7.

The development length $l_{\mathrm{d}}$ of a deformed bar in tension, in terms of bar diameter $d_{\mathrm{b}}$, can be expressed as (ACI, 2014) 

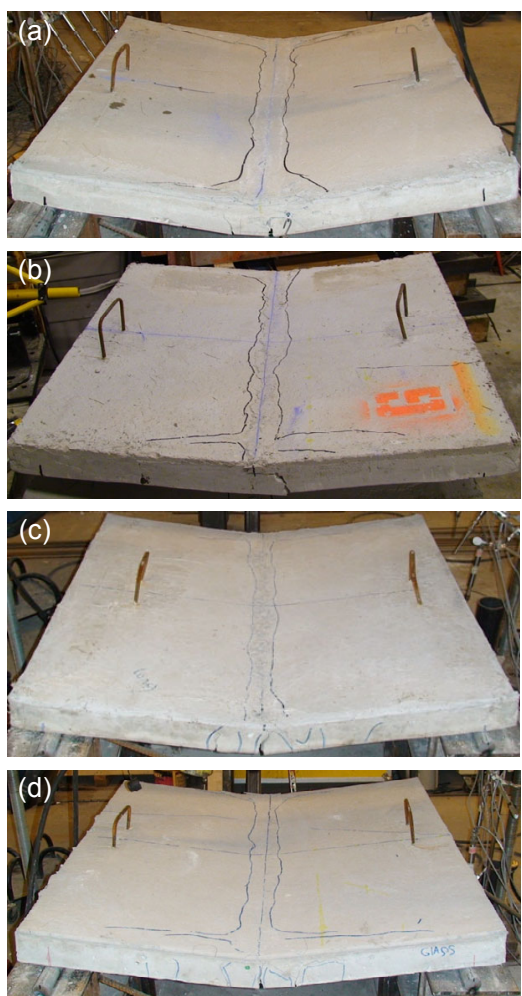

Fig. 11 Failure modes of slabs

(a) Slab E2 with $1 \%$ short uncoated fibers; (b) Slab F3 with $1 \%$ CRE-coated short fibers; (c) Slab G2 with 1\% CREcoated long fibers; (d) Slab H3 with 1\% short glass fibers
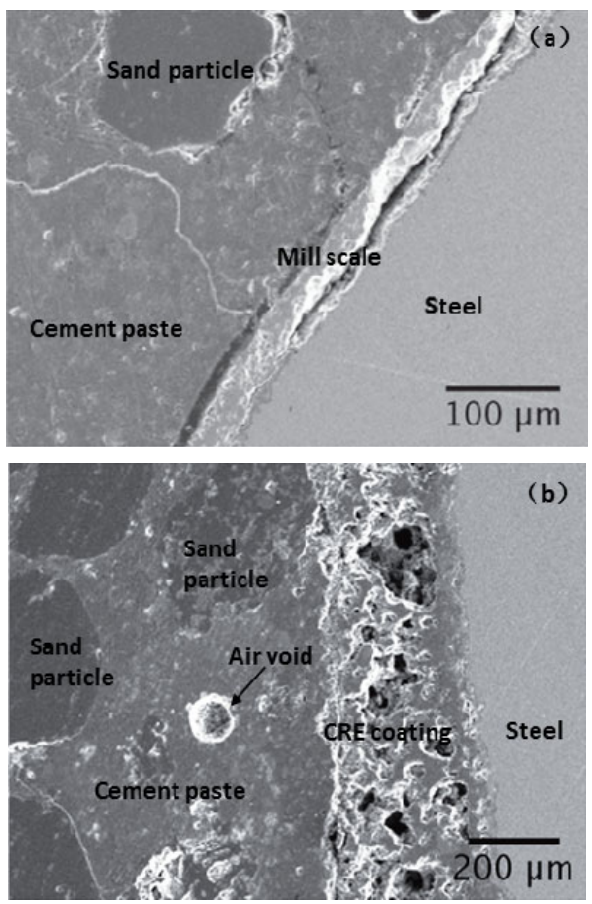

Fig. 12 SEM images of the interfaces

(a) Uncoated steel bar; (b) CRE-coated bar

$$
\frac{l_{\mathrm{d}}}{d_{\mathrm{b}}}=\frac{f_{\mathrm{y}} \alpha \beta \lambda}{25 \sqrt{f_{\mathrm{c}}}}
$$

where $\alpha$ represents the contribution of confining reinforcement across potential splitting planes and $\alpha=$ 1.0 in this study; $\beta$ is a coating factor and $\beta=1.0$ for uncoated rebar; $\lambda$ is a factor relating to the concrete and $\lambda=1.0$ for normal-weight concrete; $f_{\mathrm{y}}$ is the nominal yield strength of rebar and $f_{\mathrm{y}}=490 \mathrm{MPa}$; $f_{\mathrm{c}}$ is the 28-day compressive strength of concrete and $f_{\mathrm{c}}=$ 44.0 MPa. For $\# 10$ bars, $d_{\mathrm{b}}=9.525 \mathrm{~mm}$ and $l_{\mathrm{d}}=33 \mathrm{~cm}$. For steel fibers with $0.737 \mathrm{~mm}$ in diameter, $l_{\mathrm{d}}=26 \mathrm{~mm}$.

As shown in Fig. 4b, the span length of slabs is approximately $1040 \mathrm{~mm}$. Since the yield lines of slabs are limited mainly to a center portion of $127 \mathrm{~mm}$ to $254 \mathrm{~mm}$ as illustrated in Fig. 11, which is significantly less than the span length of the slabs, the yield strength of steel bars can be achieved without CRE coating. In this case, the concrete-steel bond strength is expected to have little or no influence on the formation of yield lines. Therefore, the effect of CRE coating applied on steel bars on the ultimate strength and ductility of slabs without fibers are insignificant as demonstrated in Table 3 when the slabs in Groups $\mathrm{B}$ and $\mathrm{D}$ are compared. However, a CRE-coated steel bar can potentially reduce local debonding from its surrounding concrete as the concrete cracks. As a result, the load-deflection curves of slabs under static loading degrade gradually with higher strength and broader plateaus as shown in Fig. 10e, leading to higher ductility that the slabs can be subjected to.

In this study, both short fibers (29.5 mm long) and long fibers (59 mm long) were considered. Since the short fibers are significantly shorter than twice the development length from Eq. (1), which is $52 \mathrm{~mm}$, CRE coating is expected to substantially affect the overall behavior of slabs, as indicated in Table 3, as the coated fibers are gradually pulled out of concrete at the locations of cracks. On the other hand, the length of long fibers is more than twice as much as the development length. As such, the yield strength of coated long fibers can be developed and the increased concrete-steel bond strength associated with CRE coating becomes not important. However, the use of steel fibers increases the compressive strength of concrete, the maximum bending moment of any cross section of slabs, and thus the ultimate strength of the 
slabs as indicated in Table 3. Furthermore, due to yielding of the steel fibers, the deflection ductility of the slabs is expected to be significantly increased as shown in Fig. 10e. To prevent steel fibers from being bundled together and/or sunk at the bottom of slabs during mixing, the length of steel fibers should not exceed $63.5 \mathrm{~mm}$ in practice.

To support the above analysis, a close examination was conducted on two slabs as shown in Fig. 13: one with coated short fibers and the other with coated long fibers. The short fibers were pulled out of concrete whereas the long fibers were broken. These observations partially validated Eq. (1) for steel fibers when a coating factor of $0.57<\beta<1.0$ is introduced (Wu et al., 2012).
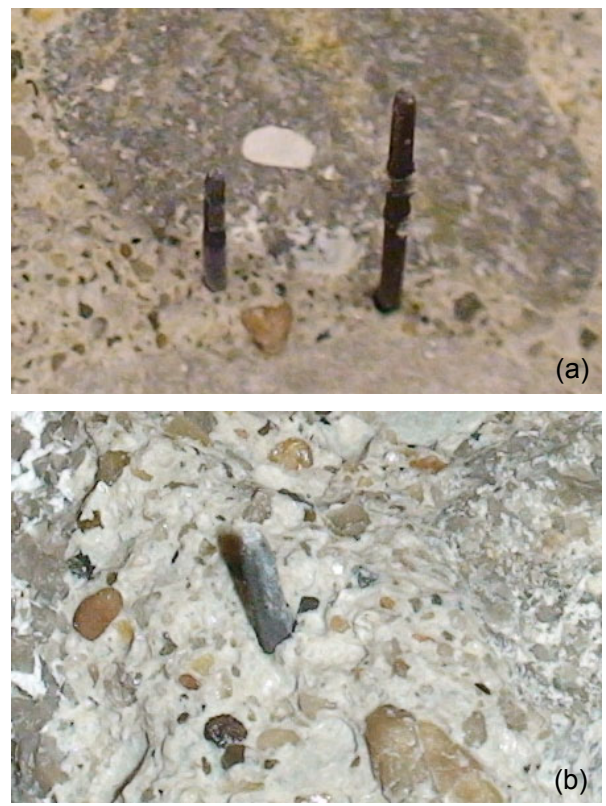

Fig. 13 Failure modes of steel fibers in concrete (a) Short fibers pulled out of concrete; (b) Long fiber fractured

\section{Conclusions}

Based on the extensive test results and analysis under static and dynamic loads, the following conclusions can be drawn:

1. CRE coating can reduce the crater area of RC slabs under a single charge by up to $20 \%$. Multiple charges from low to high explosives in blast tests can generate an over $30 \%$ smaller crater than a single charge of the same high explosive only. This is because the crater induced at low explosives allows the release of air pressure at the time of high explosives.

2. In comparison with slabs with uncoated bars, the load-deflection curves of slabs reinforced with CRE-coated bars under both static and blast loads have a relatively broad plateau and a less degradation of strength, indicating a more ductile behavior as a result of more distributed minor cracks accumulated in concrete.

3. Compared with uncoated fibers, CRE-coated fibers can increase the ultimate strength of slabs by up to $16 \%$ under static loading. Long fibers $(59 \mathrm{~mm})$ in concrete allow the development of yield strength of fibers, prevent concrete cracks from widening, and thus increase the ultimate strength of RC slabs more significantly than short fibers.

4. Although developed for reinforcing steel bars, the ACI development length equation appears applicable to steel fibers with a coating factor of $0.57<$ $\beta<1.0$. The debonding behavior of short fibers and the fracture behavior of long fibers used in the tested slabs agree well with the predictions from the ACI equation. The required development length of the short and long steel fibers can be used to consistently explain the strength and ductility of the loaddeflection curves.

Future studies are directed to the determination of a coating factor of steel fibers in the ACI development length equation in tension and the evaluation on the compressive strength of concrete reinforced with uncoated and CRE-coated steel fibers.

\section{Acknowledgements}

The authors are grateful to Mr. Mike KOENIGSTEIN (ProPerma Engineered Coatings, USA) who has prepared all CRE-coated samples for testing, and Mr. Jason COX (Missouri University of Science and Technology, USA) for his assistance in the preparation of blast tests.

\section{References}

AASHTO (American Association of State Highway and Transportation Officials), 2015. LRFD Bridge Design Specifications with 2015 Interim Revisions, 7th Edition. AASHTO, Washington DC, USA.

ACI (American Concrete Institute), 2014. Building Code Requirements for Structural Concrete and Commentary, ACI 318-2014. ACI, Farmington Hills, USA.

Allison, P.G., Moser, R.D., Weiss, C.A., et al., 2012. Nanomechanical and chemical characterization of the interface between concrete, glass-ceramic bonding enamel and 
reinforcing steel. Construction and Building Materials, 37:638-644

http://dx.doi.org/10.1016/j.conbuildmat.2012.07.066

Brown, M.C., Weyers, R.E., 2003. Corrosion Protection Service Life of Epoxy Coated Reinforcing Steel in Virginia Bridge Decks. Final Contract Report, Virginia Transportation Research Council, Charlottesville, USA.

Day, D.C., Weiss, C.A., Malone, P., et al., 2006. Innovative method of bonding Portland cement concrete to steel using a porcelain interface. Materials Science and Technology Conference Proceedings, the American Ceramic Society, Westerville, USA.

Dong, S.G., Zhao, B., Lin, C.L., et al., 2012. Corrosion behaviour of epoxy/zinc duplex coated rebar embedded in concrete in ocean environment. Construction and Building Materials, 28(1):72-78.

http://dx.doi.org/10.1016/j.conbuildmat.2011.08.026

Dusenberry, D.O., 2010. Handbook for Blast-resistant Design of Buildings. John Wiley \& Sons, Inc., USA. http://dx.doi.org/10.1002/9780470549070

Jalili, M.M., Moradian, S., Hosseinpour, D., 2009. The use of inorganic conversion coatings to enhance the corrosion resistance of reinforcement and the bond strength at the rebar/concrete. Construction and Building Materials, 23(1):233-238. http://dx.doi.org/10.1016/j.conbuildmat.2007.12.011

Kayali, O., Yeomans, S.R., 2000. Bond of ribbed galvanized reinforcing steel in concrete. Cement and Concrete Composites, 22(6):459-467.

http://dx.doi.org/10.1016/S0958-9465(00)00049-4

MacGregor, J.G., 1997. Reinforced Concrete: Mechanics and Design, 3rd Edition. Prentice Hall, New Jersey, USA.

Mindess, S., Young, J.F., Darwin, D., 2003. Concrete, 2nd Edition. Prentice Hall, New Jersey, USA.

NRC (National Research Council), 1927. International Critical Tables. McGraw-Hill, Washington DC, USA, p.116.

Sagues, A., 1994. Corrosion of Epoxy Coated Rebar in Florida Bridges. Final Report WPI No. 0510603, Florida Department of Transportation, Tallahassee, USA.

Silva, P.F., Lu, B., 2007. Improving the blast resistance capacity of RC slabs with innovative composite materials. Composites Part B: Engineering, 38(5-6):523-534. http://dx.doi.org/10.1016/j.compositesb.2006.06.015

Tang, F.J., Chen, G.D., Brow, R.K., et al., 2012a. Corrosion resistance and mechanism of steel rebar coated with three types of enamel. Corrosion Science, 59:157-168. http://dx.doi.org/10.1016/j.corsci.2012.02.024

Tang, F.J., Chen, G.D., Brow, R.K., et al., 2012b. Microstructure and corrosion resistance of enamel coatings applied to smooth reinforcing steel. Construction and Building Materials, 35:376-384. http://dx.doi.org/10.1016/j.conbuildmat.2012.04.059

Tang, F.J., Chen, G.D., Volz, J.S., et al., 2013. Cementmodified enamel coating for enhanced corrosion resistance of steel reinforcing bars. Cement and Concrete Composites, 35(1):171-180. http://dx.doi.org/10.1016/j.cemconcomp.2012.08.009
Tang, F.J., Chen, G.D., Brow, R.K., 2016. Chloride-induced corrosion mechanism and rate of enamel- and epoxycoated deformed steel bars embedded in mortar. Cement and Concrete Research, 82:58-73.

http://dx.doi.org/10.1016/j.cemconres.2015.12.015

Wu, C.L., Chen, G.D., Volz, J.S., et al., 2012. Local bond strength of vitreous enamel coated rebar to concrete. Construction and Building Materials, 35:428-439. http://dx.doi.org/10.1016/j.conbuildmat.2012.04.067

Wu, C.L., Chen, G.D., Volz, J.S., et al., 2013. Global bond behavior of enamel-coated rebar in concrete beams with spliced reinforcement. Construction and Building Materials, 40:793-801. http://dx.doi.org/10.1016/j.conbuildmat.2012.11.076

Yan, D.M., Reis, S., Tao, X., et al., 2012. Effect of chemically reactive enamel coating on bonding strength at steel/ mortar interface. Construction and Building Materials, 28(1):512-518.

http://dx.doi.org/10.1016/j.conbuildmat.2011.08.075

Zhao, B., Lin, C.J., Zhang, X.G., 2007. Corrosion behavior of epoxy coated rebar with scratch in mortar in the sea field. The 212th Electrochemical Society Meeting, Washington DC, USA.

\section{中文概要}

题 目: 活性瓷釉涂层钢筋及钢纤维增强混凝土板动、静 力学特性研究

目 的：活性瓷釉涂层能够显著增强钢筋的防腐蚀能力, 同时明显提升钢筋与混凝土的粘结力。通过对活 性瓷釉涂层钢筋以及钢纤维增强混凝土板在动、 静力荷载作用下的承载力、变形特性以及破坏特 征的研究, 为活性瓷釉涂层技术在钢筋混凝土结 构中的应用奠定理论基础。

创新点: 1 . 对活性瓷釉涂层钢筋混凝土板的动、静力学性 能进行系统研究; 2. 探究活性瓷釉钢纤维在混凝 土结构中的作用机理。

方 法: 1. 通过对活性瓷釉涂层钢筋混凝土板进行爆炸实 验（图 3)，揭示活性瓷釉涂层钢筋混凝土结构 的动力破坏特征（图 5 和 6)；2. 通过对活性瓷 釉涂层钢筋混凝土板进行静力实验 (图 4), 研 究在 “点” 荷载和 “线” 荷载作用下混凝土板的 力学性能; 3 . 通过分析钢纤维在钢筋混凝土结构 中的传力机理, 提出活性瓷釉涂层钢纤维在钢筋 混凝土结构中的设计方法 (图 13)。

结 论: 1. 活性瓷釉涂层能够显著改善钢筋在混凝土结构 中的传力性能; 在动力荷载作用下, 涂层钢筋混 凝土结构的破坏程度明显减轻。2. 活性瓷釉涂层 能够显著改善钢筋混凝土结构的变形特性, 大大 增强其耗能能力。3. 采用活性瓷釉涂层的钢纤 维, 其纤维长度可适当减小。

关键词：活性瓷釉涂层; 爆炸荷载; 破坏特征; 钢纤维 